Trakya Eğitim Dergisi

Cilt 9, Sayı 4

2019 Ek Sayı

Aralık 2019, 696-707

Geliş Tarihi: 28.01.2019

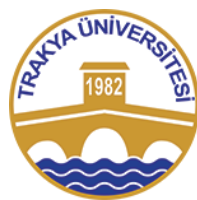

ISSN: 2630-6301
Trakya Journal of Education

Volume 9, Issue 4

2019 Additional Issue

December 2019, 696-707

DOI: $10.24315 /$ tred.518571

Yayına Kabul Tarihi: 06.12.2019

\title{
Coğrafya Bölümü Öğrencilerinin Ödev Destekli Öğretim Üzerine Görüşleri
}

\section{Opinions of Students of Geography Department on Homework-Assisted Education}

\author{
Vedat ŞAHİN ${ }^{1}$, Ziya İNCE ${ }^{2}$
}

\begin{abstract}
Öz: Ödevler, öğrencilerin üzerinde çalışmaları için verilen ve bir konu veya sorun üzerinde düşünmelerini, davranış geliştirmelerini ve öğrenmelerini amaçlar. Ödevler, öğrencinin sorumlu tutularak çoğunlukla sınıf ortamının dışında yerine getirilmesinin sağlandığı vazifelerdir. Ödev, öğretimin her kademesinde öğretimin bir parças1 olarak başvurulan bir yöntem olduğu gibi yükseköğretim düzeyinde de başvurulan bir araçtır. Ödevler ansiklopedi, ders kitabı, dergi ve istatistik verileri gibi çeşitli kayanlardan yararlanarak yapılabilmektedir. Günümüzde öğrenciler kaynaklara ulaşımının hem kolay olması, hem de çok fazla verinin bulunması nedeniyle internetten yoğun bir şekilde yararlanmaktadır. Bu çalışmada da lisans düzeyindeki coğrafya bölümü öğrencilerinin verilen ödevlerine yönelik tutumları incelenmiştir. Çalışmanın temel amacı, coğrafya bölümü öğrencilerinin ödev destekli öğretim üzerine görüşleri tespit etmek ve bu doğrultuda öneriler getirmektir. Çalışmada esas olarak nicel yöntem kullanılmış olmakla birlikte, derse giren öğretim üyelerinin gözlemleri de dikkate alınmıştır. Araştırmaya toplam 78 öğrenci katılmıştır. Çalışmada, verilerin birinci elden toplanmasına yönelik olarak uygulanan yöntem, anket tekniğidir. Elde edilen veriler SPSS 22 programı kullanılarak istatistiksel olarak analiz edilmiştir. Çalışmada uygulanan 31 maddelik anketin Cronbach's Alpha güvenirlik katsayısı 0,802 çıkmıştır. Araştırma neticesinde ödevlerin araştırmaya yönelik ve öğrencilerin öğrenmesine katkı sağlayıcı nitelikte olması gerektiğine ulaşılmıştır. Ayrıca ödevlerin çok fazla ve çok zor olmasının öğrencileri olumsuz etkilediği bulgularına ulaşılmıştır.
\end{abstract}

Anahtar sözcükler: Ödev, ögrenci, coğrafya eğitimi, yükseköğretim

\begin{abstract}
Assignments aim to lead students to think about a topic or problem, to develop a behavior and learn from it. Assignments are the responsibility of the students to fulfil a task mainly outside the classroom environment. Assignment/homework is a method used at all levels of education as a part of teaching program and it is used also as a tool at higher education level. Assignments can be carried out by using various resources such as encyclopedias, textbooks, journals and statistics. Nowadays, students benefit from internet extensively because of the fact that access to resources is easy and it is possible to reach large amount of data. In this study, the attitudes of undergraduate students of geography department towards the assignment were examined. The main purpose of the study is to determine the opinions of the geography department students on homework-supported teaching and to make suggestions in this direction. A survey was carried out to collect data. While the quantitative method was used in the study, the observations of the faculty members were also taken into consideration. A total of 78 students participated in the study. Survey method was implemented for the collection of first hand data. The data was analyzed statistically by using SPSS 22 software program. Cronbach Alpha reliability coefficient of the 31-item questionnaire was 0,802 . As a result of the research, it was determined that the assignments should be intended for research purposes and contribute to the students' learning. In addition, it was found that if assignment was too much and too difficult, the students were affected negatively.
\end{abstract}

Keywords: Homework, student, geography education, higher education

\section{Introduction}

\section{EXTENDED ABSTRACT}

One of the teaching methods implemented in Geography Departments is the assignment-supported education. The assignments are usually given to prompt better understanding of course subjects and enhance knowledge of the students. Therefore, the assignments serve as a supplement to the teaching. There are many studies in the literature about assignments at different levels of education. Some of them aim to assess the level of benefits of the assignments and some evaluate the types of assignments in terms of effectiveness. This study was conducted in order to examine and analyze the views of geography students at undergraduate levels on the subject of assignment.

\section{Method}

A survey was carried out to collect data. While the quantitative method was used in the study, the observations of the faculty members were also taken into consideration. In addition, the students' opinions about the assignments were examined without their knowledge, as the researcher talked to the students, carried out activities with them and took notes were when necessary. This study aims to reveal the reasons behind the students' behaviours related to the research subject. Furthermore, the students were asked directly about their opinions about assignments in the natural environment of the classroom. Although,

\footnotetext{
Doç. Dr., Tekirdağ Namık Kemal Üniversitesi, Fen Edebiyat Fakültesi Coğrafya Bölümü, Tekirdağ-Türkiye, vsahin@nku.edu.tr, ORCID: 0000-0002-5502-5219

2 Dr. Öğr. Üyesi, Tekirdağ Namık Kemal Üniversitesi, Fen Edebiyat Fakültesi Coğrafya Bölümü, Tekirdağ-Türkiye, zince@nku.edu.tr ORCID: 0000-0001-7398-8083
} 
the survey was the main method of data collection, the observation and interview methods were also used to confirm the accuracy of the findings and make necessary interpretation. Furthermore, the reliability and validity analyses of the items of the attitude scale were carried out.

The sample of this study consisted of $2^{\text {nd }}, 3^{\text {rd }}$ and $4^{\text {th }}$ year students studying at the Geography Department of Namik Kemal University. A total of 78 students participated in the study. Survey method was implemented for the collection of first hand data. A questionnaire was prepared with 31-item attitude statements of Likert- type in accordance with the quantitative research methods. The data was analyzed statistically by using SPSS 22 software program. The reliability analysis of the questionnaire was performed and Cronbach's Alpha reliability coefficient was found as 0.802 for 34 items of the survey.

\section{Results}

This study aims to examine the opinions of geography students about the course assignments. It is determined that $67.9 \%$ of the students think that the assignments contribute to their learning process and $89.7 \%$ of them think the assignments should be in line with the course contents and $70.5 \%$ of the students think the assignments contribute to their developments in the field of geography. However, $64.1 \%$ of the students stated that the format of the assignments were difficult, and $76.9 \%$ stated that they had difficulty in completing their assignments. Also, $67.9 \%$ of the students stated that their willingness to do assignments change according to the subject of the course.

One of the notable findings of the study is that the students want their lecturer to guide them during assignment process. $88.5 \%$ of the students stated that the lecturer should assist them when they are trying to complete their assignments. Furthermore, the students were asked if they use internet for their assignments and $94.9 \%$ of them responded positively. However, only $61.5 \%$ of the students use the library for their assignments and $79.5 \%$ of them use books. On the other hand, three quarters of the students do not like if the lectures were carried out by the student presentations. They prefer lecturer to explain the subjects. In addition, $78.2 \%$ of students stated that the assignments take a lot of time. $85,9 \%$ of the students want their assignments to be research-related. In this study, the students were asked whether the assignments should help them to prepare for the lectures and $94.9 \%$ of the students gave a positive answer.

\section{Discussion and Conclusion}

Based on the data of the study, it is determined that approximately one third of the geography students at undergraduate level are not happy with their geography assignments. Of course, several factors affect this situation. Although, a large number of students enjoy their assignments, some students find them boring. However, it is sometimes necessary to study and complete necessary duties to gain academic knowledge, even if it is boring .

It is concluded that the students respond positively if the assignments were research-related. In this respect, the assignments should be chosen in such a way to include research activities . In addition, they should also support learning process and be appropriate to the level of the students. When giving assignments, the lecturers should consider the benefits to the students and its feasibility. It is also determined that every course topic should not be given as assignment and the students should be provided with necessary guidance. Besides that, it is also important that the assignments should not bore the students.

Almost all of the students benefit from the resources on the internet while preparing their assignments and use library in lesser ratio. It is necessary to discourage the students from copying information directly from the internet. In addition, the assignments should include the student's analysis and interpretation. Thus, even if the student benefits from the internet, he/she will be encouraged to provide their a unique study. Moreover, it is necessary to make sure that the assignment time is sufficient enough and there are necessary resources available.

According to the results of the study, the students state that they spent a great deal of time for preparing and completing the assignments. Therefore, the assignments should be chosen to give them some time for social, sport and leisure activities.

In conclusion, the assignments should be research-related, should develop students' skills and contribute to their learning process. Topics should be beneficial to their studies, encourage them involve in research activities and help them to learn about current information.

\section{GíRiş}

İlköğretim ve ortaöğretimde temel ve hayata hazırlayıcı bir içerik varken, yükseköğretimde bilgiyi üretebilecek, geliştirebilecek ve kullanabilecek eğitimsel yap1 vardır (Ünlü, 2014,56). Öğrencilerin akademik birikimleri ve öğrenme yetenekleri yükseköğretime doğru gidildikçe artmaktadır. Ancak gerek ortaöğretimde gerekse yükseköğretimde, sınıf ortamı dışında da dersleri çalışmak, tekrar etmek ve araştırmalar yapmak başarı düzeyini yükseltmek için gerekmektedir. Bu nedenle yükseköğretim düzeyinde 
bile başvurulan öğretme faaliyetlerinden birisi ödev vermek ve ödev destekli öğretim gerçekleştirmek olmaktadir.

Güneş (2015) ödevi, öğrencilerin öğrendiklerini pekiştirmek amaciyla okul dışı zamanlarda bireysel olarak çözülebilecek güçte çalışma olarak tanımlamaktadır. Ödev, yakın zamanlara kadar az sorgulansa da, son dönemlerde bu konu ile ilgi çalışmalar artmıştır (Vatterott, 2009). Ayrıca dünyada uzun yıllar ödevlerin öğrenci başarısına katkısı olup olmadığı, varsa ne düzeyde olduğu hakkında araştırmalar yapılmıştır (Güneş, 2014). Bazı çalışmalar ödevin akademik başarı üzerinde etkisinin az olduğu bulgusuna ulaşırken, bazısı önemli katkılar sağladığı soncuna varmıştır (Ektem ve Yıldız, 2017; Ilgar, 2005; Turanl1, 2007; Ersoy ve Anagün, 2009). Buna rağmen ödevler, öğretimin her düzeyinde, eğitimciler için vazgeçilmez bir unsur olarak kullanılmaya devam etmiştir (Şeref ve Varışoğlu, 2015). Günümüzde ödevler, genellikle günlük olarak, dünyanın her yerindeki ve her yaştan öğrenciye verilmektedir. Ev ödevi en sık evde yapılıyor olsa da, okul veya kütüphane gibi başka yerlerde de yapılabilmektedir (Hong ve Milgram, 2000). Diğer yönden ödevlerin, bir öğretim yöntemi olarak öğretimde öğrenme ve öğretmeyi tamamlayıcı bir araç olma özelliği vardır (Yücel, 2004).

Ödevler, öğrencilerden belli konularda yapmaları istenen, böylece bilgilerini ve becerilerini geliştirmesi hedeflenen faaliyetlerdir (Gedik, Altıntaş ve Kaya, 2011; Ergün ve Özdaş, 1997). Ödevler sayesinde öğrenciler, evlerinde derslerine düzenli ve planlı olarak çalışabilirler ve tekrar yapabilirler. Ödev öğretimin bir parçası ve öğrencilerin öğrenme sürecinin bir köşe taşıdır (Painter, 2003).

Ödevi konu edinen pek çok akademik çalışma yapılmıştır. Cooper, Lindsay ve Nye (2000) tarafından yapılan çalışmada evde ödev yapma konusu ele alınmış, öğrenci, aile ve ebeveynlik tarzındaki farklılıklarının ödev süreci ile ilişkisi incelenmiştir. Bu çalışmada ilk ve ortaöğretim öğrenci, öğretmen ve veli örneklemi baz alınmış olup, veliler tarafindan destek gören öğrencilerin ödevlerinde ve notlarında daha başarılı olduğu bulunmuştur. Benli ve Sarıkaya (2012) yapmış oldukları çalışmada, öğrencilere verilen konuların anlaşılmasından ödevlerin büyük rolü olduğunu sonucunu bulmuşlardır. Aydın (2011) tarafından yapılan çalışmada, lise düzeyindeki öğrencilere yönelik olarak, coğrafya dersinde verilen ev ödevlerine ilişkin öğrenci görüşleri incelenmiştir. Coğrafya derslerine yönelik olarak hazırlanması itibariyle önemli bir boşluğu doldurmuş olan çalışmada, ödevlerin gerekli olduğu bulgusuna ulaşılmıştır. Duru ve Çöğmen (2017) yaptığı çalışma, öğrencilerin uzun okuma ve yazma gerektiren verilen ödevleri yapmaktan hoşlanmadıklarını sonucuna varmışlardır. Tertemiz'in (1991) ödevin başarıya etkisi üzerine yaptığı çalışma ise dönüt verme, düzeltme yapma ve pekiştirecin kalıcılığı sağladığı yönündedir.

Ödev konusu üzerine yapılan başka çalışmalar da vardır. Bunlardan ödevlerin öğrencilerin okula bağ l1lığ 1 , akademik başarısı ve tükenmişliği üzerine yapılan çalışmalarda ise öğrencilerin ödev yapmaya ayırdıkları zaman arttıkça bıkkınlığın ve tükenmişliğin yükseldiği bulunmuştur (Öztan, 2014; Özdemir, 2015). Literatür incelendiğinde ödev destekli öğretim üzerine çok sayıda çalışma olduğu görülmektedir. Bunlardan bazısı ilköğretim düzeyinde, bazısı ortaöğretim düzeyinde yapılmıştır. Bu çalışma ise yükseköğretim düzeyindeki coğrafya bölümü lisans öğrencilerinin görüşleri dikkate alınarak yapılmıştır.

Gerek Türkiye'de gerekse dünyada ödevlerin nasıl verileceği ve ne kadar faydalı olacağı araştırılmıştır. Bu yönü ile özellikle ödev vermenin amacı ve sebeplerinin öğrencilere iyi açıklanması, ödevlerin bilinçli yapılmasını sağlaması itibariyle önemlidir (Calp, 2012). Bu çalışmada da lisans düzeyindeki coğrafya bölümü öğrencilerinin ödev destekli bir öğretimi nasıl buldukları araştırılmıştır. Öğrencilerin ödevler ile ilgili olan çeşitli düşünceleri tespit edilmeye ve analiz yapılmaya çalışılmıştır.

\section{YÖNTEM}

Çalışmada esas olarak nicel yöntem kullanılmış olmakla birlikte, derse giren öğretim üyelerinin gözlemleri de dikkate alınmıştır. Nicel araştırmanın temel özelliği verilerin toplanması ve analizinde sayısallaştırmaya önem verilmesidir (Öztürk, 2014, 68). Gözlem, araştırma grubuna hissettirmeden ve araştırma yapıldığını bildirmeden yapılan gözlemler sonucu verilerin toplanmasıdır (Küçük, 2016, 72). Katılımlı gözlem metodunda ise, araştırmacı verileri toplarken topluluk içinde aktif olarak yer alarak kişilerin davranışlarını doğrudan gözlemleyerek, kişilerle konuşarak davranışlarının sebeplerini araştırmaktır (Baş ve Alturan, 2017). Bu çerçevede, bu çalışmanın verilerinin toplanması esnasında öğrencilerin ödevlerle ilgili görüşleri onlara hissedilmeden takip edilmiş, onlarla konuşulmuş, öğrencilerle birlikte aktiviteler yapmış ve gerektiğinde notlar alınmıştır. Böylece öğrencilerin araştırma konusu ile ilgili davranışlarının arkasındaki nedenleri ortaya çıkarmak istenmiştir. Ayrıca sınıf içinde ve doğal ortamın niteliksel yapısına özen gösterilerek öğrencilere ödevler ile ilgili olarak, doğrudan görüşleri sorulmuş ve araştırmada bunlara da gerektiğinde yer verilmiştir. Bu nedenle çalışmada esas olarak veri toplamaya yönelik olarak anket yöntemi kullanılmış olsa da, bulguların doğruluğunu teyit etmek ve doğru yorumlamak 
amacıyla gözlem ve görüşme yöntemlerinden de yararlanılmıştır. Ayrıca araştırmada uygulanan tutum ölçeğinin maddeleri ile ilgi güvenirlik ve geçerlik çalışmaları yapılmıştır.

\section{1. Örneklem}

Örnek, bir bütünün niteliklerini temsil eden ve ondan alınmış parçadır (Doğanay, 2002, 6). Bu araştırmanın örneklemini Namık Kemal Üniversitesi coğrafya bölümünde okuyan, 2., 3. ve 4. Sınıf öğrencileri oluşturmaktadır. Araştırmaya toplam 78 öğrenci katılmıştır. Bunlardan 30 öğrenci 2. Sınıfta olup bunların 14 bayan ve 16's1 erkektir. 26 öğrenci ise 3. Sinıfta okumakta olup, bunların 13'ü erkek ve 13'ü bayandır. Dördüncü sınıf öğrencilerinin sayısı 22 olup, bunların 10’u bayan ve 12'si erkektir.

\subsection{Veri Toplama Aracı}

Çalışmada, verilerin birinci elden toplanmasına yönelik olarak uygulanan yöntem, anket tekniğidir. $\mathrm{Bu}$ yöntem öğrencilerin bir durum karşısında tutum ve beklentilerini belirlemede en yaygın kullanılan yöntemlerdendir. Bu sayede gözlemler belli standartlar çerçevesinde veriye dönüşmektedir. Bu çerçevede öncelikle problemin tanımlanmasının yapılması ve ankete konu olan maddelerin kayda geçirilesi gerekir. Sonraki aşamada ise uzman görüşleri ile anket soruları ve konunun çerçevesi değerlendirilesine geçilir (Büyüköztürk, 2005). Bu bağlamda hazırlanan ölçek önce bir sınıfta, 22 öğrenciye uygulanarak test edilmiş, uzman görüşleri doğrultusunda gözden geçirilmiş ve uygulamaya konan anket maddeleri böylece ortaya çıkarılmıştır. Bu yönüyle ölçeğin, amacını doru olarak ölçebilmesi hususuna dikkat edilmiş ve geçerliğin yüksek olması sağlanmıştır.

$\mathrm{Bu}$ araştırmada, nicel araştırma yöntemlerine uygun olarak, araştırma problemini ve alt problemlerini kapsayan, likert tipi anket olarak hazırlanmış 31 maddelik tutum cümlesi yer almıştır. Ankette dereceleme beş maddeden oluşan; "Tamamıyla Katılıyorum", "Çok Fazla Katılıyorum", "Kat1liyorum", “Az Katılıyorum" ve "Katılmıyorum" seçeneklerinden oluşan derecelendirme kullanılmıştır. Hazırlanan anket, öncelikle coğrafya alanında çalışma yapan uzmanların görüşlerine sunulmuş ve bu araştırmacıların görüşleri doğrultusunda düzenlemelere de yer verilerek son şekli verilmiştir. Araştırma kullanılan tutum ölçeğinin geliştirilmesinde, literatür taraması esnasında karşılaşılan konu üzerine yapılmış çalışmalardan da esinlenerek, veri toplama aracı olarak kapsamlı bir tutum ölçeği oluşturulmuştur.

\subsection{Verilerin Analizi}

Verilerin çeşitli yöntemleri ile toplandıktan sonra anlamlı bir hale getirilmesi, analiz edilerek raporlaştırılması ve bulguların sunulması istatistik olarak isimlendirilir. Böylece elde edilmiş verilerin özellikleri daha anlaşı1ır hale getirilmiş olur. Bu çalışmanın anketinde, güvenirlik analizi Cronbach's Alpha modeli ile gerçekleştirilmiştir. Cronbach's Alpha değerinin 0.70 ve üstü olduğu durumlarda ölçeğin güvenilir olduğu kabul edilir (Durmuş, Yurtkoru ve Çinko, 2016). Çalışmada yer alan anketteki 31 madde SPSS programı kullanılarak istatistiksel olarak analiz edilmiş, Cronbach's Alpha güvenirlik katsayısı 0,802 çıkmıştır. Dolayısı ile çalışmanın güvenirliği oldukça yüksektir.

\section{BULGULAR}

Lisans düzeyindeki öğrencilerin coğrafya bölümündeki eğitimleri esnasında verilen ödevlere yönelik tutumlarının incelendiği bu çalışmada öğrencilere 34 maddelik bir anket uygulanmış olup, elde edilen verilerin frekans (F) ve yüzdeleri (\%) tablo halinde gösterilmiştir (Tablo 1).

Tablo 1: Lisans düzeyinde coğrafya bölümü öğrencilerinin ödev üzerine görüşleri

\begin{tabular}{|c|c|c|c|c|c|c|c|c|c|c|c|}
\hline \multirow[b]{2}{*}{ No } & \multirow{2}{*}{ Tutum Sorusu } & \multicolumn{2}{|c|}{$\begin{array}{l}\text { Tamamiyla } \\
\text { Katılıyorum }\end{array}$} & \multicolumn{2}{|c|}{$\begin{array}{l}\text { Çok Fazla } \\
\text { Katıliyorum }\end{array}$} & \multicolumn{2}{|c|}{ Katıliyorum } & \multicolumn{2}{|c|}{ Az Katıliyorum } & \multicolumn{2}{|c|}{ Katılmıyorum } \\
\hline & & $\mathrm{F}$ & $\%$ & $\mathrm{~F}$ & $\%$ & $\mathrm{~F}$ & $\%$ & $\mathrm{~F}$ & $\%$ & $\mathrm{~F}$ & $\%$ \\
\hline 1 & $\begin{array}{l}\text { Coğrafya ile ilgili ödevleri yapmaktan } \\
\text { memnunum. }\end{array}$ & 14 & 17,9 & 10 & 12,8 & 29 & 37,2 & 16 & 20,5 & 9 & 11,5 \\
\hline 2 & $\begin{array}{l}\text { Coğrafya ile ilgili ödevleri sıkıcı } \\
\text { buluyorum. }\end{array}$ & 12 & 15,4 & 9 & 11,5 & 10 & 12,8 & 24 & 30,8 & 23 & 29,5 \\
\hline 3 & $\begin{array}{l}\text { Verilen ödevlerin araştırmacı olmama } \\
\text { katkısı var }\end{array}$ & 14 & 17,9 & 20 & 25,6 & 24 & 30,8 & 16 & 20,5 & 4 & 5,1 \\
\hline 4 & $\begin{array}{l}\text { Verilen ödevlerin öğrenmeme katkısı } \\
\text { var. }\end{array}$ & 12 & 15,4 & 14 & 17,9 & 29 & 37,2 & 16 & 20,5 & 7 & 9 \\
\hline 5 & $\begin{array}{l}\text { Verilen ödevlerin dersleri öğrenmeme } \\
\text { fayda sağlıyor }\end{array}$ & 13 & 16,7 & 17 & 21,8 & 23 & 29,5 & 18 & 23,1 & 7 & 9 \\
\hline
\end{tabular}




\begin{tabular}{|c|c|c|c|c|c|c|c|c|c|c|c|}
\hline 6 & $\begin{array}{l}\text { Ödevlerin ders içerikleri ile uygun } \\
\text { olması gerekir }\end{array}$ & 18 & 23,1 & 24 & 30,8 & 28 & 35,9 & 4 & 5,1 & 4 & 5,1 \\
\hline 7 & Çok zor ev ödevleri verilmektedir & 11 & 14,1 & 20 & 25,6 & 19 & 24,1 & 13 & 16,3 & 15 & 19,2 \\
\hline 8 & Çok fazla ödev verilmektedir & 16 & 20,5 & 18 & 23,1 & 26 & 33,3 & 12 & 15,4 & 6 & 7,7 \\
\hline 9 & $\begin{array}{l}\text { Ev ödevleri coğrafya ile ilgili dikkat } \\
\text { yeteneğimi artırdı }\end{array}$ & 12 & 15,4 & 8 & 10,3 & 28 & 35,9 & 17 & 21,8 & 13 & 16,7 \\
\hline 10 & $\begin{array}{l}\text { Ödevleri derslerde sunmak faydalı } \\
\text { olmaktadır }\end{array}$ & 13 & 16,7 & 12 & 15,4 & 22 & 28,2 & 17 & 21,8 & 14 & 17,9 \\
\hline 11 & $\begin{array}{|lcc|}\text { Bazı ödevlerin sunu olarak } \\
\text { hazırlanması faydalı olmaktadır }\end{array}$ & 10 & 12,8 & 11 & 14,1 & 23 & 29,5 & 22 & 28,2 & 12 & 15,4 \\
\hline 12 & $\begin{array}{l}\text { Ödevleri yapmak coğrafya alanında } \\
\text { gelişmemi sağladı }\end{array}$ & 12 & 15,4 & 19 & 24,4 & 24 & 30,8 & 17 & 21,8 & 6 & 7,7 \\
\hline 13 & $\begin{array}{l}\text { Zor olmamak şartı ile mutlaka ödev } \\
\text { verilmelidir }\end{array}$ & 14 & 17,9 & 19 & 24,4 & 21 & 26,9 & 16 & 20,5 & 8 & 10,3 \\
\hline 14 & $\begin{array}{l}\text { Coğrafya ile ilgili de olsa dersine göre } \\
\text { ödev yapma arzum değişmektedir. }\end{array}$ & 9 & 11,5 & 16 & 20,5 & 28 & 35,9 & 17 & 21,8 & 8 & 10,3 \\
\hline 15 & $\begin{array}{l}\text { Ödevleri yapmakta dersin hocasının } \\
\text { katkısı olmalıdır }\end{array}$ & 17 & 21,8 & 33 & 42,3 & 19 & 24,4 & 4 & 5,1 & 5 & 6,4 \\
\hline 16 & $\begin{array}{l}\text { Ev ödevleri her zaman bir yük olarak } \\
\text { tarafimca algılanmaktadır. }\end{array}$ & 12 & 15,4 & 16 & 20,5 & 14 & 17,9 & 18 & 23,1 & 18 & 23,1 \\
\hline 17 & $\begin{array}{|lc|}\begin{array}{l}\text { Ödevleri yaparken } \\
\text { yararlanmaktayım }\end{array} & \text { internetten } \\
\end{array}$ & 19 & 24,4 & 29 & 37,2 & 26 & 33,3 & 2 & 2,6 & 2 & 2,6 \\
\hline 18 & $\begin{array}{l}\text { Ödevlerimi yaparken kütüphaneden } \\
\text { yararlanmaktayım }\end{array}$ & 8 & 10,3 & 13 & 16,7 & 27 & 34,6 & 16 & 20,5 & 14 & 17,9 \\
\hline 19 & $\begin{array}{|lc|}\text { Ödevlerimi yaparken kitaplardan } \\
\text { yararlanmaktayım }\end{array}$ & 10 & 12,8 & 21 & 26,9 & 31 & 39,7 & 10 & 12,8 & 6 & 7,7 \\
\hline 20 & $\begin{array}{l}\text { Coğrafya dersinde öğretmenimin } \\
\text { sınıfta kendisinin ders anlatması } \\
\text { yerine, ödev verip konuları öğrencilere } \\
\text { anlattırması, konuyu anlamamı } \\
\text { zorlaştırmaktadır. }\end{array}$ & 15 & 19,2 & 30 & 38,5 & 15 & 19,2 & 12 & 15,4 & 6 & 7,7 \\
\hline 21 & $\begin{array}{l}\text { Öğrencilere ödev yaptırmayı gereksiz } \\
\text { olarak görüyorum. }\end{array}$ & 6 & 7,7 & 9 & 11,5 & 14 & 17,9 & 19 & 24,4 & 30 & 38,5 \\
\hline 22 & $\begin{array}{l}\text { Ödevlerin, sınav notuna yansımasını } \\
\text { doğru buluyorum. }\end{array}$ & 22 & 28,2 & 13 & 16,7 & 25 & 32,1 & 10 & 12,8 & 8 & 10,3 \\
\hline 23 & $\begin{array}{l}\text { Sınavlarda ödev konularından } \\
\text { sorulmasını doğru buluyorum. }\end{array}$ & 11 & 14,1 & 14 & 17,9 & 26 & 33,3 & 17 & 21,8 & 10 & 12,8 \\
\hline 24 & $\begin{array}{l}\text { Verilen ödevler dersleri daha iyi } \\
\text { pekiştirmeme neden olmaktadır }\end{array}$ & 12 & 15,4 & 8 & 10,3 & 28 & 35,9 & 20 & 25,6 & 10 & 12,8 \\
\hline 25 & $\begin{array}{|llll|}\text { Ödev yapmak çok fazla zaman } \\
\text { almaktadır }\end{array}$ & 9 & 11,5 & 30 & 38,5 & 22 & 28,2 & 12 & 15,4 & 5 & 6,4 \\
\hline 26 & $\begin{array}{|lcc|}\text { Ödevleri yetiştirme } & \text { konusunda } \\
\text { zorluklara yaşamaktayım } & \\
\end{array}$ & 15 & 19,2 & 24 & 30,8 & 21 & 26,9 & 11 & 14,1 & 7 & 9 \\
\hline 27 & Ödevler araştırma ağırlıklı olmalıdır & 13 & 16,7 & 18 & 23,1 & 36 & 46,2 & 9 & 11,5 & 2 & 2,6 \\
\hline 28 & $\begin{array}{l}\text { Ödevler dersleri ögrenmeye hazırlayıcı } \\
\text { nitelikte olmalıdır }\end{array}$ & 12 & 15,4 & 29 & 37,2 & 33 & 42,3 & 3 & 3,8 & 1 & 1,3 \\
\hline 29 & $\begin{array}{l}\text { Ödev verildikten sonra, ödevin hangi } \\
\text { kriterlere göre yapılacağının } \\
\text { belirtilmesi daha nitelikli ödevler } \\
\text { yapmama neden olmaktadır }\end{array}$ & 15 & 19,2 & 23 & 29,5 & 27 & 34,6 & 9 & 11,5 & 4 & 5,1 \\
\hline 30 & $\begin{array}{l}\text { Ödevlerin sadece konusu ders hocası } \\
\text { tarafindan verilsin, nasıl yapılacağına } \\
\text { benim karar vermem gerekir }\end{array}$ & 8 & 10,3 & 15 & 19,2 & 30 & 38,5 & 16 & 24,5 & 9 & 11,5 \\
\hline 31 & $\begin{array}{l}\text { Ödevler beni derslere karşı motive } \\
\text { etmektedir }\end{array}$ & 11 & 14,1 & 4 & 5,1 & 20 & 25,6 & 19 & 24,4 & 24 & 30,8 \\
\hline
\end{tabular}


Lisans düzeyindeki öğrencilerin coğrafya bölümünde verilen ev ödevlerine yönelik tutumlarının incelendiği bu çalışmada, öğrencilere yöneltilen "Coğrafya ile ilgili ödevleri yapmaktan memnunum" maddesine verdikleri cevapların yüzdeleri incelendiğinde; katılıyorum, çok fazla katılıyorum ve tamamen katılıyorum, diyenlerin oranları toplamı \%67,9 olarak çıkmaktadır. Buna karşılık, az katılıyorum veya katılmıyorum diyenlerin oranı \%32,1 olarak çıkmaktadır. Bu yönü ile öğrencilerin yaklaşık üçte biri coğrafya ile ilgili ödevleri yapmaktan memnun değildir.

"Coğrafya ile ilgili ödevleri sıkıcı buluyorum" maddesine, öğrencilerin \%39,7'si "katıldıklarını" veya daha yüksek düzeyde katılıyor olduklarını, ifade etmişlerdir. Öğrencilerin \%59,3'ü ise buna az veya hiç katılmadıklarını belirmişlerdir. Dolayısı ile öğrencilerin büyük bir kısmı ödevleri sıkıcı bulmamaktadır. Yine öğrencilerin önemli bir kısmı ödevleri hem sıkıcı bulmakta hem de ödev yapmaktan ötürü memnun kalmamaktadır.

Araştırmada öğrencilere yöneltilen "Verilen ödevlerin araştırmacı olmama katkısı var", maddesine $\% 74,4$ oranında katılıyorum veya daha yüksek düzeyde katılıyorum, denilmiştir. Öğrencilerin yaklaşık dörtte biri ise buna katılmadıklarını ifade etmişlerdir. Bundan hareketle öğrencilere verilen ödevlerin araştırmaya destek olucu özelliğinin yüksek olduğu, fakat daha iyi ve araştırma açısından nitelikli ödevlerin seçilmesi gerektiği ortaya çıkmaktadır.

Araştırmadaki maddelerden birisi "Verilen ödevlerin öğrenmeme katkısı var" şeklinde olmuştur. bu maddeye öğrencilerin \%70,5'i katılıyorum veya daha yüksek düzeyde katıllyorum, cevabını vermişlerdir. Bundan hareketle ödevlerin, öğrenmeyi destekleyici olduğu sonucuna varılabilir. Bununla birlikte \%29,5'lik kısmın, öğrenmeyi desteklemediği, yönünde düşüncesi vardır. $\mathrm{Bu}$ açıdan, öğrencilere verilen ödevlerin öğrenmeye katkısının olduğu sonucuna varmak mümkün olmakla birlikte, ödevlerin öğrenmeyi daha çok destekleyici şekilde olması gerektiği sonucuna da varılmaktadir.

Tablo 1'in beş numaralı tutum sorusunda "Verilen ödevler dersleri daha iyi öğrenmeme fayda sağlıyor" maddesine yönelik verilen frekans ve yüzde değerleri yer almaktadır. Buna göre öğrencilerin \%67,9'u verilen ödevlerin dersleri daha iyi öğrenmelerine katkı sağladığını düşünmektedir. Bu soru ile "Verilen ödevlerin öğrenmeme katkısı var" maddesi içerik bakımından önemli oranda benzeşmekte olduğu gibi verilen cevapların yüzdesi de örtüşmektedir. Buna göre öğrencilerin verilen ödevlerden daha yüksek düzeyde istifade edebilmesi için ödevler verilirken, öğrencilerin öğrenmelerini destekleyici olması ve dersleri daha iyi kavramalarını sağlaması gerektiğini özellikle dikkate almak gerekir.

Çalışmada öğrencilere yöneltilen "Ödevler, ders içerikleri ile uygun olmalıdır" maddesine, \%89,7 oranında katılıyorum veya daha yüksek düzeyde katılıyorum, denilmiştir. Ödevler verilirken görülen dersin programı dikkate alınarak ve öğrencilerin görmekte olduğu konular dikkate alınarak verilmelidir. Bu durumda öğrencilerin daha yüksek düzeyde faydalanacakları aşikardır.

Çalışmaya konu edilen bir diğer madde "Çok zor ev ödevleri verilmektedir" konusudur. Buna öğrencilerin \%64,1'i katılıyorum veya daha yüksek düzeyde katılıyorum derken, az katıldıklarını veya katılmadıklarını ifade edenlerin oran $1 \% 35,9$ olarak tespit edilmiştir. Diğer maddelerle de ilişkili olarak bu oranlar incelendiğinde öğrencilerin yaklaşı üçte biri ödev verilmesinden memnun olmadığı gibi ödevleri faydasız ve zor olarak değerlendirmektedir. Bu bakımdan ödevler verilirken, öğrencilerin seviyelerinin mutlaka dikkate alınması, hangi konularda ve nasıl ödevler verilmesi gerektiği, önemlidir. Her konunun ödev olarak verilmesi, nasıl yapılacağı hususunda bir yol göstericiliğin bulunmaması ve öğrencinin yapabilirlik düzeyi dikkate alınması gereken hususlar olarak ortaya çıkmaktadır.

Diğer bir tutum maddesinde öğrencilerin "Çok fazla ödev verilmektedir" konusundaki görüşleri tespit edilmek istenmiştir. Bu maddeye öğrencilerin \%76,9'u katılıyorum veya daha yüksek düzeyde katılıyorum cevabını verirken, $\% 23,9$ 'u az veya hiç katılmadıklarını ifade etmişlerdir. Buna göre öğrencilerin yaklaşık dörtte üçü kendilerine fazla ödev verilmediği görüşündedir.

Araştırmaya öğrencilerin "Ev ödevleri coğrafya ile ilgili dikkat yeteneğimi artırdı" konusundaki görüşlerine de yer verilmiş olup, bu maddeye öğrencilerin $\% 61,5$ 'i katıllyorum veya daha yüksek düzeyde katılıyorum, cevabını vermişlerdir. Ancak öğrencilerin $\% 38,5^{\prime}$ lik bir bölümü buna ya hiç katılmadıklarını ya da az katıldıklarını, belirtmişlerdir. Bundan hareketle ödevlerin, öğrencilerin kısmen dikkat yeteneğini geliştirmeye yönelik olduğu sonucuna varılabilmektedir.

Araştırmaya konu edinilen bir diğer madde "Ödevleri derslerde sunmak faydalı olmaktadır". Buna öğrencilerin en yüksek düzeyle $\% 28,2$ 'lik bir oran katıllyorum, cevabını vermişlerdir. Bununla 
birlikte toplam olarak katılıyorum veya daha yüksek düzeyde katılıyorum, cevabını verenlerin oranı \%60,3 düzeyinde kalmaktadır. Dolayısı ile öğrencilerin önemli bir kısmı, çeşitli nedenlere bağlı olarak, yapmış oldukları ödevleri ders esnasında arkadaşlarına sunmalarını ve derste anlatmalarını olumlu karşılamamaktadır. Bu konu ile ilintili olarak öğrencilere "Bazı ödevlerin sunu olarak hazırlanması faydalı olmaktadır" maddesine yer verilmiş ve öğrencilerin farklı bir yönden bu hususla ilgili düşünceleri tespit edilmeye çalışılmıştır. Bu maddeye öğrencilerin vermiş oldukları cevaplar incelendiğinde, katıllyorum $(\% 29,5)$ ve az katılıyorum $(\% 28,2)$ diyenlerin oranlarının birbirine yakın olduğu görülmektedir. Ancak katılıyorum veya daha yüksek oranda katılıyorum, cevabını verenlerin toplam oranı $\% 56,4$ 'te kalmaktadır. Bu oranlar da göstermektedir ki, bir kısmı ödevlerin sunu olarak (powerpoint sunusu) hazırlanmasını ve derste sunulması olumlu karşılarken, yine önemli bir bölümü faydalı bulmamaktadır.

Araştırmaya konu edinilen bir başka husus "Ödevler yapmamın öğrencilerin coğrafya alanında gelişmesini sağlayıp sağlamadığı” konusudur. Öğrencilerin en fazla oranla \%30,8'i buna katıldıklarını ifade etmişlerdir. Ayrıca ödev yapmanın coğrafya alanında gelişmelerine katkı sağladığını düşünenlerin toplam oranı \% 70,5'tir. Buna az veya hiç katılmadıklarını belirtenlerin oranı ise \%29,5'tir. Bundan hareketle önemli bir oranda coğrafya ödevleri, öğrencilerin gelişimlerine katk1 sağlamaktadır. Bu hususla ilintili olarak, öğrencilere "Zor olmamak şartı ile mutlaka ödev verilmelidir” maddesi yöneltilmiş̧tir. Bu iki maddeye verilen cevap oranları birbiri ile örtüşmektedir. Buna göre öğrencilere mutlaka ödev verilmelidir, cevabını olumlu karşılayanların oranı \%69,2 iken, buna katılmayanların toplam oranı \%31,8'dir. Buna göre öğrencilere, onların yapabilecekleri, gelişmelerine katkı sağlayacak nitelikte ve zor olmamak şartı ile ödev verilmelidir.

Araştırmaya konu olan maddelerden birisi "Coğrafya alanı ile ilgili de olsa, dersin konusuna göre ödev yapma arzum değiş̧mektedir”. Bu hususta öğrencilerin toplamda \%67,9'u bunun doğruluğunu ifade etmiş̧lerdir. En büyük oranı ise \%35,9 ile katıllyorum, diyenler oluşturmuş̧tur. Buna karşılık az veya hiç katılmayanların toplam oranı \%32,1 olarak çıkmıştır. Buna göre öğrencilerin yaklaşık üçte biri dersin konusuna göre, ödev yapma hususunda isteğinin değiştiğini, arttığını veya azaldığını ifade ederken, büyük bir kısmı coğrafya alanı içinde ödev yaparken ayrım yapmadığını ifade etmişlerdir.

Çalışmada yer verilen diğer bir husus öğrencilerin "Ödevleri yapmakta derse giren öğretim üyesinin katkısı” ile ilgili düşünceleridir. Buna göre \%88,5’i ödevi veren öğretim üyesinin katsının olması gerektiğini ifade etmişlerdir. Buna az katılıyorum veya hiç katılmıyorum, cevabını verenlerin toplam oranı ise sadece \%11,5 düzeyindedir. Bu açıdan öğrenciler, ödevleri yaparken öğretim üyelerinin katkısı ile yapıldığında daha faydalı olacağını ve daha iyi sonuçlar elde edeceğini ifade etmişlerdir.

Ödev yaparken öğrencilerin hangi tür kaynakları kullandıkları da önemlidir. Bu amaca yönelik olarak öğrencilere internet, kütüphane ve kitaplar olarak üç başlık altında sorular yöneltilmiştir. Bunlardan "Ödevleri yaparken internetten yararlanmaktayım" maddesine yönelik olarak, öğrencilerin \%94,9'u katılıyorum veya daha yüksek düzeyde katıllyorum, demişlerdir. Bu verilerden hareketle öğrencilerin nerdeyse tamamı ödev hazırlama konusunda internetteki kaynaklara baş vurduğu görülmektedir. Bu durum öğrencilerin teknolojiyi eğitim amaçlı kullanmaları yönüyle olduğu gibi hem güncel hem de çok çeşitli kaynakları kullanabilmeleri bakımından önemlidir.

Öğrencilere yöneltilen "Ödevlerimi yaparken kütüphaneden yararlanmaktayım” maddesine yönelik olarak, öğrencilerin \%61,5'i katıllyorum veya daha yüksek düzeyde katılıyorum, cevabını vermişlerdir. Az veya hiç katılmadığını ifade edenlerin oranı ise $\% 38,5$ 'tir. Verilerde de görüldüğü gibi internetten faydalanarak ödev yapma alışkanlığı kütüphaneden faydalanarak, ödev yapma oranından çok daha yüksek düzeylerdedir. Bu yönüyle kütüphanedeki coğrafya ile ilgili kaynakların artırılmasının yanında, kütüphane de ödev yapılabilecek olanakların artırılması faydalı olacaktır.

Öğrencilerin “Ödevlerimi yaparken kitaplardan yararlanmaktayım” maddesine yönelik olarak vermiş oldukları cevaplar incelendiğinde $\% 79,5$ 'i katıllyorum veya daha yüksek düzeyde katılıyorum, cevabını vermiş̧lerdir. Bunlar içinde \%39,7 ile katılıyorum, diyenler en yüksek düzeyde olandır. Bu çerçevede ele alındığında öğrenciler ödev yaparken en fazla internetteki kaynakları kullandıkları, sonra kitaplardan yararlandıkları ve en az da kütüphaneyi kullandıkları sonucuna varılmaktadır.

Öğrencilere yöneltilen "Öğretim üyesinin dersi anlatması yerine, ödev verip konular1 öğrencilere anlattırması, konuyu anlamamı zorlaştırmaktadır” maddesine verilen cevaplar içinde en 
yüksek oranı $(\% 38,5)$ "çok fazla katılıyorum” oluşturmaktadır. Bu maddeye katılıyorum veya daha yüksek düzeyde katılıyorum, cevabını verenlerin toplam oranı \%76,9'dur. Dolayısı ile öğrencilerin dörtte üçü, öğrenciler tarafından ödev çerçevesinde konuların anlatılmasını olumlu karşılamamakta ve dersleri öğretim üyelerinin anlatmasını istemekte, öğrenciler tarafindan derste konuların anlatılmasını öğrenmeyi zorlaştırıcı olarak bulmaktadır. Ancak diğer bir maddede öğrencilerin "Öğrencilere ödev yaptırılmasını gereksiz olarak görüyorum” görüşleri tespit edilmek istenmiştir. Bu madde öğrencilerin, anket içinde \%7,7 ile en düşük "tamamıyla katılıyorum" onayı verdikleri maddedir. Diğer yönden bu maddede öğrencilerin \%37,2'si ödev verilmemesi gerektiğini ifade ederken, \%62,8'i ödev verilmesini olumlu bulmuştur. Bu iki madde ele alındığında, öğrenciler önemli oranda ödev verilmesine olumlu bakarken, öğretim amaçlı olarak öğrencilere ödev verilmesi neticesinde sadece dersleri kendilerinin anlatması ve öğretim üyelerinin ders anlatarak öğrencilerin öğrenmelerine yardımcı olmamalarını desteklememektedirler. Dolayısı ile öğretim üyeleri her ne kadar ödev yaptırsalar da ders işlenirken, dersleri öğrencilere anlattırmak yerine, kendilerinin anlatması gerekmektedir.

Öğrencilere yöneltilen "Ödevlerin, sınav notuna yansitılmasını doğru buluyorum" ifadesine $\% 76,9$ oranında katılıyorum veya daha yüksek düzeyde katılıyorum, cevabı verilmiştir. Ayrıca öğrencilerin bu ankette "tamamıla katılıyorum" şıkkı ile ilgili olarak \% 28,2 ile en yüksek oranda çıkmıştır. Dolayısı ile öğrencilerin önemli bir oranda yapmış oldukları ödevlerin ders içerikleri ile örtüşmesini ve sınav notuna yansıtılmasını istemektedir. Öğrencilere yöneltilen (tablo 26) "Sınavlarda ödev konularından sorulmasını doğru buluyorum" ifadesine ise öğrencilerin \%65,4’ü katılıyorum veya daha yüksek düzeyde katılıyorum, demişlerdir. Dolayısıyla öğrencilerin yaklaşık üçte birlik kısmı, ödev konuları ile ilgili sınav sorusunu yersiz bulmaktadır. Öğrenciler yapmış oldukları ödevlere emek harcadıklarından sınav notlarına yansıtılması isterken, her ödev konusunun sınavda yer almasını önemli bir oranda olumsuz bulmaktadır. Bunda öğrencilerin hazırlamış oldukları ödevleri, ayrıca sınıfta kendilerinin sunmalar, ancak bunun yeterince öğretici nitelikte olmaması öğrenciler için ayrıca bir yük olarak algılanmaktadır.

Araştırmada "Ödev yapmak çok fazla zaman almaktadır" konusuna yer verilmiştir. Buna öğrencilerin \%78,2'si katılıyorum veya daha yüksek düzeyde katılıyorum, cevabını vermişleridir. Özellik "çok fazla katılıyorum", diyenlerin oranı \%50 olması dikkat çekmektedir. Dolayısı ile öğrencilerin yoğun şekilde ödev yaptıkları ve zamanlarının önemli bir kısmını ödev hazırlamakla geçirdikleri görülmektedir.

Çalışmada yer verilen hususlardan bir tanesi "ödevler araştırma ağırlıklı olmalıdır" konusudur. Buna öğrencilerin \%85,9'u katılıyorum veya daha yüksek oranda katılıyorum, cevabını vermişlerdir. Dolayısı ile öğrencilerin büyük kısmı ödevler verilirken, araştırmaya yönelik olmasını istemektedir. $\mathrm{Bu}$ durum akademik nitelik ve bilimsel olarak öğrencilerin gelişimleri açısından önemlidir. Dolayısı ile öğrenciler araştırma yapmayı büyük oranda istemekte ve kendilerinin araştırmacı olarak yetiştirilmelerini desteklemektedirler.

Araştırmada, verilen ödevlerin öğrencileri derslere karşı öğrenmeye hazırlayıcı olup olmaması gerektiği sorulmuştur. Buna verilen cevapların \%94,9 gibi çok büyük oranı, katılıyorum veya daha yüksek oranda katılıyorum, şeklinde olmuştur. Buna katılmıyorum veya hiç katılmıyorum, cevabını verenlerin oranı ise sadece $\% 5,1$ 'de kalmıştır. Dolayısı ile verilen ödevler öğrencilerin konuları öğrenmeleri açısından hazırlayıcı olma niteliğini taşımalıdır.

\section{TARTIŞMA VE SONUÇ}

Yapılan çalı̧̧manın verilerinden hareketle lisans düzeyinde coğrafya eğitimi alan öğrencilerin yaklaşık üçte biri coğrafya ile ilgili ödevleri yapmaktan memnun değildir. Bu durum üzerinde çeşitli unsurların etkili olduğu şüphesizdir. Bununla birlikte öğrencilerin büyük bir kısmı ödevleri sıkıc1 bulmamakta, bir kısmı ise ödevleri sıkıcı bulmaktadır. Ancak şunu belirtmek gerekir ki, bazen sıkıcı da olsa akademik bilgi edinmek için insanın çalışması ve yeterli birikimi elde etmesi gerekir.

Çalışmada öğrencilerin araştırmayı destekleyici ödevler verilmesini olumlu buldukları sonucuna varılmıştır. Bu açıdan ödevlerin, araştırma yönü yüksek ve geliştirici nitelikte olması gerekliliği vardır. Ayrıca öğrenciler, ödevlerin öğrenmeyi destekleyici mahiyetinin bulunmasını olumlu karşılamaktadır. Bu bakımdan ödevler verilirken araştırma ve öğrenme özelliklerinin bulunması gerekliliği vardır. Diğer yönden öğrencilerin ödevlerden yüksek seviyelerde istifade edebilmesinde dersleri daha iyi kavraması gerektiği sonucuna varılmışır. Bunun yanında öğrenciler ödevlerin, ders içerikleri ile uygun olmasını ve ödevler verilirken yapılan derslerin dikkate alınmasını 
faydalı bulmaktadır. Diğer maddelerle de ilişkili olarak bir çıkarım yapıldığında, öğrencilerin bir kısmı ödev verilmesinden memnun olmadığı gibi ödevleri faydasız ve zor olarak değerlendirirken, az da olsa bir kısmı kendilerine fazla ödev verildiği görüşündedir. Dolayısı ile öğrencilerin bir kısmı ödevleri yaparken zorlanmamakla birlikte, bir kısmı ödev için fazla zaman yetirmekte ve verilen ödevleri kendi seviyesine uygun bulmamaktadır. Elde edilen bulgular Ekici ve Akdeniz'in (2018) yapmış oldukları çalışma ile örtüşmektedir. Bu çalışmalarda da, ödevlerin yoğun bir şekilde ve öğrencilerin istekleri dikkate alınmadan verilmesinin, motivasyonu olumsuz etkilediği bulgusuna ulaşılmıştır. Bu bakımdan ödevlerin, öğrencilerin seviyesine uygun olması gerekir. Nasıl ödevler verileceği üzerinde düşünülerek, faydalılık esas alınarak ve yapılabilirliğine dikkat edilerek verilmelidir. Özellikle derste yer alsa da her konunun ödev olarak verilmemesi, nasıl yapılacağ hususunda bir yol göstericilik ve rehberliğin yapılması gerekliliğinin olduğu sonucuna varılmış, öğrencilerin ödevi özellikle yapabilirlik düzeyinin dikkate alınması gerektiği bulgusuna ulaşılmıştır.

Yapılan araştırma neticesinde ödevlerin, öğrencilerin önemli bir kısmının dikkat yeteneğini geliştirmeye katkı sağladığı görülmüştür. Bu madde çerçevesinde konuya yaklaşıldığında, ödevlerini özenle, araştırarak yapılabilen ve bıkkınlık göstermeyen tarzda olması gerekmektedir. Bu çerçevede nitelikli ödevlerin öğrencilerin hem öğrenme düzeylerini hem de coğrafya konuları üzerindeki dikkat yeteneklerini geliştiğini söylemek mümkündür.

Araştırmada, öğrencilerin önemli bir kısmı, çeşitli nedenlere bağlı olarak, yapmış oldukları ödevleri ders esnasında arkadaşlarına sunmalarını ve derste anlatmalarını olumlu karşılamadıklarını ifade etmişlerdir. Dolayısı ile öğrencileri bir kısmı ödevlerin sunu olarak (powerpoint sunusu) hazırlanmasını ve derste sunulması faydalı bulmaktadır. Ancak öğrencilerin önemli bir bölümünün bunu faydalı bulmaması, öğretim üyelerinin dersleri sadece öğrencilere anlattırması, öğrencilerin birçoğunun anlatım yeteneklerinin henüz tam olarak gelişmemiş olması ile de ilgilidir. Dolayısı ile öğrencilerin anlamakta ve anlatmakta zorlandığ 1 ve isteksiz olduğu konularda, ödev ya hiç verilmemesi ya da çok özen göstererek bilinçli bir şekilde verilmesi gerekmektedir.

Araştırmanın sonucunda elde edilen bulgulardan birisi, coğrafya ödevlerinin, öğrencilerin gelişimlerine katkı sağladığı yönündedir. Bu hususla ilgili olarak, öğrencilere, zor olmamak şartı ödev verilip verilmemesi gerekliliği sorulmuş ve bunun neticesine göre öğrenciler, onların yapabilecekleri, gelişmelerine katkı sağlayacak nitelikte ve zor olmamak şartı ile ödev verilmesi gerektiğini ifade etmişlerdir.

Araştırma neticesine göre öğrencilerin büyük bir kısmı coğrafya alanı çerçevesinde olması şartıyla, ödev yaparken ayrım yapmamaktadır. Ancak az da olsa bir kısmı dersin konusuna göre, ödev yapma hususunda isteğinin değiş̧tiğini, arttığını veya azaldığını ifade etmişlerdir. Bu durum öğrencilerin coğrafya ile ilgili de olsa, kendilerinin ilgisinin daha yüksek olduğu, fiziki coğrafya, beşerî coğrafya veya bölgesel coğrafya gibi konuları tercih etmeleri ile ilgili olabilir. Diğer yönden öğrenciler, ödevleri yaparken öğretim üyelerinin katkısı ile yapıldığında daha faydalı olacağını ve daha iyi sonuçlar elde edeceğini ifade etmişlerdir.

Çalışmada yer verilen konulardan birisi ise öğrencilerin ödev hazırlarken internet, kitap veya kütüphaneyi ne oranda kullandıklarını tespit etmeye yönelikti. Bu çerçevede, öğrencilerin nerdeyse tamamı ödev hazırlama konusunda internetteki kaynaklara baş vurmaktadır. Arıkan ve Altun'un (2007) araştırması ile bu çalışmanın verileri örtüşmekte olup, her iki çalışmanın sonuçlarına göre öğrencilerin büyük bir bölümünün ödevlerini yaparken internete başvurdukları görülmektedir. $\mathrm{Bu}$ durum öğrencilerin teknolojiyi eğitim ve öğrenme amaçlı kullanmalarını göstermektedir. Ayrıca internetteki güncel coğrafya kaynaklarından öğrencilerin gerektiğinde istifade edebileceklerini göstermektedir. Ödevler verilirken, internette daha önce yapılmış, doğrudan indirip telim etmeyi özendirici olmaktan uzak ve öğrencinin analiz ve yorumlarını içeren nitelikte olmasına özen göstermelidir (Sarı̈öz, 2011).

Bunun yanında internetten faydalanarak ödev yapma alışkanlığı kütüphaneden faydalanarak ödev yapanlardan çok daha yüksek düzeylerdedir. Bu yönüyle kütüphanedeki coğrafya ile ilgili kaynakların artırılmasının ve kütüphanedeki ders çalışma yeterliklerinin artırılması faydalı olacaktır. $\mathrm{Bu}$ neticeler göre öğrenciler, ödev yaparken en fazla internetteki kaynakları kullanmakta, sonra kitaplardan yararlanmakta ve en az da kütüphaneyi kullanmaktadır. Arıca öğrencilerin önemli bir sorunu ödev yaparken kaynak bulma sorunu yaşamalarıdır. Bu durum Bal'ın (2012) yapmış olduğu çalışmadaki ögrencilerin zaman ve kaynak sorunu yaşadıklarını bulgusuyla örtüşmektedir (Kapıkıran ve Kıran (1999). Dolayısı ile ödev verilirken, ödevin yapılabilme süresinin yeterli olmasını, kaynak bulunurluğunu ve ödevin yapılabilirliğini dikkate almak gerekir. 
Araştırma neticesine göre öğrenciler, ödevlerin sınav notlarına yansıtılmasına önemli oranda olumlu baksa da her ödev konusuna sinavlarda yer verilmesini istememektedir. Diğer yönden öğrenciler, yoğun olarak ödev yaptıklarını ve zamanlarının önemli bir kısmını ödev hazırlamakla geçirdiklerini ifade etmiş̧lerdir. Bundan hareketle, öğrencilerin bütün zamanını almayan, onlara gezme, eğlenme ve spor gibi sosyal aktivitelere de zaman bırakılacak düzeyde ödev verilmesi gerekir. Öğrencileri bıkkınlık düzeyinde ödevlerle uğraşmaya sevk eden çalışmalar, öğrenme ve istekliliğ̆i de olumsuz etkilemektedir. Öğrenciler bunun yerine ödevlerin, konuları öğrenmeleri açısından hazırlayıcı olma niteliği taşıması gerektiğini ifade etmektedirler. Diğer yönden, ödevlerin kontrol edilmesi ve dönütler verilmesi öğrencilerin çalışma, araştırma, öğrenme ve nitelikli ödevler yapma düzeylerine fayda sağladığı ve aynı zamanda bu yönüyle Aladağ ve Doğu'nun (2009) çalışmaları ile örtüştügü görülmüştür. Dolayısı ile sadece ödev vermek ve bunları kontrol edip bırakmak yerine; öğrencilere yapmış oldukları ödevdeki olumlu ve olumsuz yönleri açıklamak, daha iyi nasıl çalışmaları nasıl yapabileceklerini izah etmek sonraki ödevlerin niteliğini olumlu etkilemektedir. olursak;

Yapılan çalışmadan hareketle bir takım öneriler getirmek mümkündür. Bunları özetleyecek

- Dersler işlenirken sıkıcılıktan uzak olmaya özen göstermek gerekir. Bu bağlamda çeşitli araç gereçlerin ve farklı ögretim yöntemlerinin ders işlenişinde kullanılması faydalı olacaktır.

- Ödevler verilirken öğrencilerin gelişimi göz önünde buldurulmalı, araştırma gerektiren, yaparak öğrenme ve tecrübe elde etmeye yönelik ödevler verilmelidir.

- Ödevler öğrencilerin seviyesine uygun olarak ve yapabilecekleri düzeyde olmalıdır. Öğrencilerin seviyesinin üstünde olan ve faydası az ama çok fazla zaman alıcı ödev tarzlarından sakınmak gerekir.

- Verilen ödevlerin sınıf ortamında anlattırılması, öğrencinin bir takım yeteneklerinin gelişmesi bakımından gereklidir. Bununla birlikte dersin odak noktasına öğrencilerin anlatımına dayanan ve diğer öğrencilerin öğrenmesini engelleyen yöntemleri koymaktan sakınılması gerekir. Bu bağlamda konun özelliğine göre bilimsel derinliği olan, temel ve önemli konuları mutlaka derse giren öğretim üyesinin anlatması gereklidir.

- Yapılan ödevler, dersin öğretim üyesi tarafindan kontrol edilmeli, doğrular, eksikler ve yanlışlar mümkün olduğunca öğrencilere açıklanmalıdır. $\mathrm{Bu}$ bağlamda motivasyonu yükseltmek ve yapılan ödevlerin anlamsız olmadığ 1 algısını oluşturma için öğrencilere ödevler ile ilgili dönütler verilmesi gerekir.

- Ödevler araştırmaya yönelik, becerilerin geliştirilmesine uygun ve öğrencilerin öğrenmesine katkı sağlayıcı olmalıdır.

- Konular kullanışlı bir tarza sahip olmalı ve güncel verilere bilgilere ulaşmaya yönelik olmalidir.

- Ödevler çok fazla, çok zaman alıcı ve çok zor olmamalıdır. Ayrıca hazırcı, kopyacı ve baştan savmacılığı özendirici yaklaşımlardan uzak olmalıdır. 


\section{KAYNAKLAR}

Aladağ, C. \& Doğu, S. (2009), Fen ve teknoloji dersinde verilen ödevlerin öğrenci görüşlerine göre değerlendirilmesi. Selçuk Üniversitesi Sosyal Bilimler Enstitüsü Dergisi, 2, 16-23.

Arıkan, Y.D., \& Altun, E. (2007). Sınıf ve okulöncesi öğretmen adaylarının çevrimiçi ödev sitelerini kullanımına yönelik bir araştırma. Illkögretim Online, 6(3), 366-376.

Aydın, F. (2011). Coğrafya dersinde verilen ev ödevlerine ilişkin öğrenci görüşler. Pamukkale Üniversitesi Eğitim Fakültesi Dergisi, 29, 27-41.

Bal, A. P. (2012). İlköğretim öğrencilerinin matematik dersi performans görevi hazırlama sürecine ilişkin görüşleri ve yaşadıkları sorunlar. Pegem Eğitim ve Öğretim Dergisi, 2 (1), 11-24.

Baş, T., \& Akturan, U. (2017). Sosyal bilimlerde bilgisayar destekli nitel araştırma yöntemleri. Ankara: Seçkin Yayıncilik.

Benli, E., \& Sarıkaya M. (2012). Fen ve teknoloji dersinde verilen ödevlere yönelik ilköğretim 2. kademe öğrencilerinin sınıf düzeyleri ve cinsiyete göre görüşlerinin değerlendirilmesi. Kastamonu Eğitim Dergisi, 21(2), 489-502.

Büyüköztürk, Ş. (2005). Anket geliştirme. Türk Eğitim Bilimleri Dergisi, 3 (2), 133-151.

Calp, Ş. (2012). İlköğretimde ev ödevi beşinci sınıf öğrencilerinin algıları. Uluslararası Sosyal Bilimler Eğitimi Dergisi-USBED, 1 (2), 120-136.

Cooper, H., Lindsay, J.J., \& Nye, B. (2000). Homework in the home: how student, family, and parenting-style differences relate to the homework process. Contemporary Educational Psychology, 25, 464-487.

Doğanay, H. (2002). Coğrafya ögrretim yöntemleri. İstanbul: Aktif Yayınları.

Durmuş, B., Yurtkoru, E. S., \& Çinko, M. (2016). Sosyal bilimlerde spss ile veri analizi. İstanbul: Beta.

Duru, S., \& Çöğmen, S. (2017). İlkokul ve ortaokul öğrencileri ile velilerin ev ödevlerine yönelik görüşleri, İlköğretim Online, 16(1), 354-365.

Ekici, G., \& Akdeniz, H. (2018). Lise öğrencilerinin ödev kavramına ilişkin metaforik algılarının incelenmesi. Bayburt Ĕgitim Fakültesi Dergisi, 13 (25), 135-16.

Ektem, I. Ş., \& Yıldız, S. B. (2017). İngilizce ev ödevlerine yönelik öğretmen görüşleri. Ç.Ü. Sosyal Bilimler Enstitüsü Dergisi, 26 (3), 78-91.

Ergün, M., \& Özdaş, A. (1997). Öğretim ilke ve yöntemleri. İstanbul: Kaya Matbaacılık.

Ersoy, A., \& Anagün, Ş. S. (2009). Sinıf öğretmenlerinin fen ve teknoloji dersi ödev sürecine ilişkin görüşleri. Necatibey Ĕgitim Fakültesi Elektronik Fen ve Matematik Ĕ̈itimi Dergisi, 3 (1), 58-79.

Gedik, N., Altıntaş, E., \& Kaya, H. (2011). Fen ve teknoloji derslerinde verilen ev ödevleri hakkındaki öğrenci görüşleri. Jurnal of European Education, (1), 6-13.

Güneş, F. (2014). Eğitimde ödev tartışmaları. Bartın Üniversitesi Eğitim Fakültesi Dergisi, 3, (2), 1 - 25.

Güneş, H. (2015). Eğitim bilimleri terimleri sözlüğ̈̈. Ankara: Ütopya Yayınevi.

Hong, E., \& Milgram, R. M. (2000). Homework: motivation and learning preference. London: Bergin \& Garvey Publication.

Ilgar, Ş. (2005). Ev ödevlerinin öğrenci eğitimi açısından önemi. Hasan Ali Yücel Eğitim Fakültesi Dergisi, 1, 119134.

Kapıkıran, Ş., \& Kıran, H. (1999). Ev ödevinin öğrencinin akademik başarısına etkisi. PAÜ, Eğitim Fakültesi Dergisi, $5,54-60$.

Küçük, O. (2016). Bilimsel araştırma yöntemleri. Bursa: Ekin Yayınevi.

Özdemir, Y. (2015). Ortaokul öğrencilerinde okul tükenmişliği: ödev, okula bağlılık ve akademik motivasyonun rolü. Adnan Menderes Üniversitesi Eğitim Fakültesi Eğitim Bilimleri Dergisi, 6(1), 27-35.

Öztürk, M. (2014). Coğrafya eğitiminde araştırma. Ankara: Pegem Akademi.

Painter, L. (2003). Homework. New York: Oxford University Press.

Sarısöz, O. (2011). Ortaöğretim öğrencilerinin kimya derslerinde verilen ev ödevleri hakkındaki düşüncelerinin değerlendirilmesi. Electronic Journal of Vocational Colleges, 2, 80-87.

Şeref, İ., \& Varışoğlu B. (2015). İlköğretim 7. ve 8. sınıf öğrencilerinin Türkçe dersi ödevleri hakkında görüşleri. Uluslararası Türk Eğitim Bilimleri Dergisi, 4, 93-105.

Tertemiz, N. I. (1991). Ödevin başarıya etkisi. Eğitim ve Bilim Dergisi, 81, 33-45.

Turanlı, A. S. (2007). Gerçek bir ikilem: ödev vermek ya da vermemek. Sosyal Bilimler Araştırmaları Dergisi, 1, 136154.

Ünlü, M. (2014). Coğrafya öğretimi. Ankara: Pegem Akademi.

Vatterott, C. (2009). Rethinking homework: best practices that support diverse needs. New York: Ascd. 
Yücel, A. S. (2004). Ortaöğretim düzeyindeki öğrencilerin kimya derslerinde verilen ev ödevlerine karşı tutumlarının incelenmesi. Gazi Ĕgitim Fakültesi Dergisi, 24 (1), 147-159. 